\title{
THE EDIBILITY APPROACH, CHEMICAL ECOLOGY AND RELATIONALITY. METHODOLOGICAL AND ETHNOBOTANICAL CONTRIBUTIONS
}

\author{
IWA KOEODZIEJSKA ${ }^{\mathrm{a}, \mathrm{b}, \mathrm{c}}, \mathrm{MONIKA} \mathrm{KUJAWSKA}^{\mathrm{d}}$ \\ ${ }^{2}$ INSTITUTE OF SLAVIC STUDIES, POLISH ACADEMY OF SCIENCES \\ ${ }^{\mathrm{b}}$ INSTITUTE OF ETHNOLOGY AND CULTURAL ANTHROPOLOGY, UNIVERSITY OF WARSAW \\ ${ }^{\circ}$ UNIVERSITY OF WARSAW BOTANIC GARDEN \\ d UNIVERSITY OF LODZ, INSTITUTE OF ETHNOLOGY AND CULTURAL ANTHROPOLOGY
}

\begin{abstract}
This paper combines ethnographic and ethnobotanical fieldwork with the edibility approach (EA), chemical ecology and Ingold's ontology of dwelling. The EA aims to "push harder onto and through the boundaries between edible plants and the human-animals that eat them to consider the outcomes produced as a result of these interacting materials" (Attala 2017, 130). This approach places ingestion in the light of multispecies entanglement. As proposed by Attala, this is still a philosophically "open" concept, of limited operational use in ethnographic (ethnobotanical) study. Our article argues for an expansion of the EA, based on this combined perspective and giving more attention to cross-species interactions placed in an environmental context. Our cases are about how people live with plants, exemplified by foraging practices of agriculturists in Ukraine, Daghestan and Argentina. The everyday social relations of our interlocutors are more-than-human interactions, and in these relations we pay a close attention to non-cultivated edible plants. We present two modes of writing ethnographies, in which we focus respectively on a single plant taxon or a group of plants, and where both people and plants are protagonists. We argue that incorporating the dwelling perspective and chemical ecology into the EA is one of the potentially fruitful approaches to the analysis of plant - people relations. The use of language and of the tools of ecology in an attempt to present different aspects of co-dwelling of people and plants, although it may seem anchored in Cartesian dualism, in fact allows for a deeper understanding of the relations among protagonists and their co-dwellers in the environment, and hence goes against dualisms. The relations and the ways through which organisms co-create their environment are the very essence of ecology. The close collaboration of anthropologists, ethnobotanists, ecologists and chemical ecologists is postulated in the article.
\end{abstract}

KEYWORDS: relational anthropology, edibility approach, dwelling perspective, foraging, Ukraine, Daghestan, Atlantic Forest, Argentina 


\section{INTRODUCTION}

This paper combines ethnographic and ethnobotanical fieldwork with the edibility approach, chemical ecology and Ingold's ontology of dwelling. 'The article argues for an expansion of the edibility approach based on this combined perspective, aiming to give more attention to cross-species interactions placed in an environmental context in the study of foraging practices and the use of wild edible plants by humans.

Recent intellectual projects, such as the ontological turn, not only aim at creating a more symmetrical dialogue between different ontological perspectives but also, importantly, search for a way out of a dichotomic and hierarchical approach to environments, non-human-animals and plants (Daly et al. 20r6; Holbraad and Pedersen 20I4; Kirksey 20I4). Conceptual frameworks, such as multispecies ethnography, and the more-than-human and edibility approaches, challenge the human privileged position that has tended to dominate Western scholarship since the Enlightenment, attempting to describe and analyse human entanglement with other organisms in a more symmetrical relationship (Attala 20I7; Kohn 20I3; Tsing 20I5; van der Veen 20I4). The Edibility Approach (EA) proposed by Luci Attala (20I7; 20I9) conceptualises eating as a process "which is not achieved by the individual alone but rather emerges as a relationship where the brute materiality of engaging parties - the eater and the eaten - blend together in concert as flesh-becoming" (Attala 2019, xx). What are often referred to as metabolic processes, Attala recognises as a method by which "bodies of different species fundamentally and profoundly engage with each other" (Attala 2019, xx). This approach views ingestion through the optic of multispecies entanglement (Attala 20I7, I25). Plants "eat sun" and people consume plants - these simple facts and complex processes shape relations. The point here is to present an aspect of human relationships that is often overlooked - specifically that people live with and are composed of the materials of the world, rather than just using them. Moreover, this concept draws our attention towards the porosity of species' boundaries previously highlighted by other scholars (Haraway 2008; Tsing 2015).

Perceiving plants as resources for humans is linked to one of the main constructs of modernist discourse: the dichotomy of nature and society (Pálsson 1996, 64), a dichotomy which capitalism attempts to strengthen and naturalise (Marder 2013). Plant utility does not have to be linked to commodity logic, exploitation, paternalism or conservation, i.e. modes wherein humans see their goals as above those of others and decide what is beneficial to them and to other organisms. Rather, the utility of humans to animals and plants, and vice versa, may be constructed through encounters

I Each author's contribution in the conceptual development and writing of this article is identitcal. 
and built via different types of relationships. Plants influence people's organisms by being eaten, but plants also benefit sometimes from being ingested. Michael Marder's claim is that "[p]lant-thinking does not oppose the use of fruit, roots, and leaves for human nourishment, rather what it objects to is the total and indiscriminate approach to plants as materials for human consumption within the deplorable framework of the commodified production of vegetal life" (Marder 2013, I84).

Timothy Johns has suggested that "people eat food not nutrients" (Johns I994, 52). People have good reasons and the means to avoid eating unpalatable foods, such as bitter, pungent, astringent tastes, which contain phytochemicals - but nevertheless, as many studies show, people do not avoid unpalatable plants in their diet. Within the edibility approach, we maintain that people may eat secondary chemical compounds consciously. Hence, our claim here is that people both eat food (we take into account the complexity of the term) and chemical compounds. Chemical ecology is an extensive field of research, which largely concentrates on chemical compounds present in plants and their role in the interactions between organisms, including humans. The classical model of human chemical ecology argues that human ingestion of plant chemicals is part of an integrated adaptive response, which has biological and cultural components (Johns 1990; 1994). This general premise is not compatible with our approach, nor with the search for the way out from the nature-culture dichotomy. Nevertheless, some conceptual and technical aspects of chemical ecology have offered an important perspective in a number of studies dedicated to foraging practices (Grivetti 2006), in addressing processes of domestication and the genetic diversity of some staple foods (Johns 1990; McKey et al. 20IO), and in studying the overlapping contexts of medicinal and food plant use (Etkin 1993).

Edible plants contain both primary metabolites, such as amino acids and proteins, simple sugar, carbohydrates, vitamins, minerals and plant hormones, as well as secondary metabolites (also called secondary compounds or allelochemicals) (Johns 1990; Klaser Cheng 20I7). Allelochemicals are "chemicals by which organisms of one species affect the growth, health, behaviour or population biology of another species"; they are also described as plant defensive chemicals (Whittaker and Feeny 1971, as cited in Johns 1990, 5). Plants are sessile, in other words they cannot locomote, and therefore they protect themselves from being overgrazed by producing allelochemicals in roots, bark and leaves; but because the plant's strategy is to produce offspring in numbers that can be dispersed over a large distance, generally few allelochemicals are produced in fruits, which increases their edibility (Moerman 1994). Allelochemicals play an important part in the communication and interaction of plants, as well as between plants and other phyla (Karben, Shiojiri, Ishizaki 20II; Witzany 2006). By bringing the chemical-ecological perspective into anthropological research, we do not wish to analyse plants as "convenient and healthful storehouses of calories, carbohydrates, or 
other units of stored energy" (Marder 20I3, I85). Instead, we wish to point out that the perspectives of ecology and chemical ecology may give additional insight into processes of foraging, into food preferences and food avoidance, and into propagation strategies, with all of the above resulting from the ways people dwell in their environments. This perspective helps to understand the complex ecological webs of relations between people, plants, animals, objects and environments. To notice and understand these relations, imaginative engagement is needed, similar to that postulated by Willis in The Ethnographic Imagination (2000). To be able to imagine potential relations between plants and the people collecting and consuming them, and to remain open to less obvious connections, is an essential ability in this research. Some knowledge of natural sciences, e.g. chemistry and ecology, is required for the more-than-human exploration of these potential interrelations. These scientific insights play the role of the eye of the needle that "ethnography" plays in Willis's understanding (2000, viii).

Attala (2017; 2019) concentrates on the relationship which is created between the eater (human) and what is eaten (plant). She exemplifies the EA by discussing the agential properties of psychoactive plants in some Amerindian contexts. We, on the other hand, focus not only on the eating process, but also on foraging and food making practices, for which we need the broader ecological approach offered by Ingold's dwelling perspective (2000). We are going to apply this perspective both to the eater and to what is eaten. Within the human condition, foraging and food making requires enskillment and active engagement in the environment. What should also be taken into account is that the relation with eaten plants extends into the environment in which a given plant dwells and continuously becomes with. Therefore, within both the human and the plant condition, dwelling is an active engagement with one's environment. According to Ingold's approach to dwelling, it is human and non-human animals which are endowed with the capacity of building - the generation of forms (Ingold 2000, 172-18I). This capability is not extended to plants. We, however, think that plants, although they seem very different due to their sessile nature and distributed self (Marder 2013), can be seen as dwellers too. They are beings "immersed in the currents of the lived worlds" (Ingold 20II, IO) and through their chemical traces they shape environmental conditions for their successors. Moreover, the plants' forms, which are seen as much more than just their life-forms, but include the chemical compounds, arise from the relational involvement in the surroundings.

\section{METHODS}

Our cases are about how people live with plants, as exemplified in the foraging practices of agriculturalist groups living in three different parts of the world. Complementary 
to their agricultural activity, these people collect non-cultigens/wild edible plants for consumption. Our cases come from three separate, larger research projects: one concerns practicing plant knowledge in general terms and in all domains in Eastern Podilia (Ukraine), another the particular domain of edible plants of the Shiri people (Daghestan), and the third medicinal and food plants in the Atlantic Forest. In the cases, we employ different scales of people and plant encounters. While the Ukraine and Daghestani cases concentrate on one plant taxon and a small number of human protagonists, the Atlantic Forest case introduces a greater number of people and plants. Although the research projects differ in their techniques of data collecting, the main methods applied are ethnographic - participant observation, semi-structured, unstructured and in-depth interviews; cognitive - free-listing (free elicitation of plant species names used or known in a particular domain, for example of non-cultivated edible plants), ethnobotanical - walks in the woods and cataloguing of plants stored by interlocutors (Martin 2004). Forest walks are more or less experimentally organised forms of participant observation of plant collection, during which participants are asked to collect or show plant species they know or usually collect (Thomas et al. 2007). Within each project, herbarium specimens were collected, determined and deposited according to the project: in the herbarium of the University of Warsaw Botanic Garden, the Botanical Garden of the Ivan Franko National University of Lviv, and in the herbarium IBONE, Corrientes, Argentina. Precise taxonomic identifications of plant species were an important starting point in the search for literature concerning the phytochemical composition and pharmacological properties of the plants discussed. Within each project, expression of consent was required before each interview and it was accordingly obtained in verbal or written form.

Both researchers are female, with a background in anthropology and ethnobotany. IK is also a biologist. Our research was performed much more with people than with plants (cf. Noorani and Brigstocke 2018), because the plants in many respects were seen both through the lenses of our interlocutors and of ourselves, lenses which were, to some extent, influenced by biological and ecological perspectives. We acknowledge that the everyday social relations of our interlocutors are more-than-human social relations, and pay particular attention to the plant agents involved in these relations. Noorani and Brigstocke (2018) see such an attitude as the base for research with more-than-human actors not on them. Donna Haraway (2008) postulates that researchers should take the ethical responsibility to avoid treating other-than-human research participants as passive objects. We do take this responsibility and through EA, chemical ecology and the dwelling perspective, we show plants as active. We see the tools of ecology as helping us to see the otherness of plants and their autonomous existence, instead of assimilating them to "human frames of reference" (Noorani and Brigstocke 20I8, 20). 


\section{CASE STUDIES}

\section{Edibility in disturbed times and habitats. Case study from Podilia, Ukraine} Protagonists: human - babka $a^{2}$ Stasia and plant - akacia (Robinia pseudoacacia L.). ${ }^{3}$ In 2013, as a part of a larger research study (conducted in the years 2012-2018), 30 hours of video-recordings were co-created by pupils of a local primary school and anthropology students from the University of Warsaw. This case is based on a video-recorded interview with a local expert. The language of the research was surzhyka local mixture between Ukrainian and Russian.

In 2013 , babka Stasia, the protagonist of the case study, was a 75 year old Roman Catholic woman, living in a village in Vinnytsia oblast (region) - Central Ukraine, in the geographic region of Podilia. In the period 2012 and 2018, the majority of the over I500 villagers belonged to the Ukrainian Orthodox Church (Moscow Patriarchate), whilst less than $1 / 5$ of inhabitants were members of the Roman Catholic Church. The village is located in the forest-steppe zone - a transitional zone between forests in the west and steppe in the south and east (Bohn et al. 2004), formed in a subcontinental climate. The prevailing habitat types in the area are broad-leaved deciduous forests, coexisting with sharply delimited patches of meadow steppe of the South Bug Basin (Kuzemko et al. 20I4). Forest and meadow patches are often referred to in everyday conversations. Rich, grey forest soils provide favourable conditions for agriculture, especially for fruit production (Kuzemko et al. 20I4). Two big agricultural companies are major employers in the area: their flagship crops are apple varieties. Babka Stasia was very proud (as was typical for my interlocutors) of the recreational herbal teas she makes. Collecting edible and medicinal plants is part of the local and national identity (Kołodziejska-Degórska 20I6). Moreover, in the context of plant collecting, safety arguments based on a distrust of producers and the state are common in the village (cf. Caldwell 20II; Gabriel 2005), and for some interlocutors economic arguments are important as well.

When we ${ }^{4}$ arrived at her house, babka Stasia greeted us warmly and said that she was keen on taking part in the film about people and plants in her village. When asked by two of the local schoolgirls, she started to talk about the plant species she

$2 B a b k a-a$ term used to address elder women, a sign of respect and affinity. I refer to her in the article in the way she was referred to and addressed in the village.

3 In the first instance, I give the local name and official Latin plant name (following The Plant List). The letter as part of the Latin name is an abbreviation of the last name of the person who described and named the species, an interesting indication of plant-human entanglement. I give here only local names that case protagonists used. There are more names that function simultaneously for the same taxon in the village and in the idiolects of particular village dwellers.

4 Jana and Kristina (I2 year-old girls from the village), Olga and Rafał (ethnology students from Warsaw), Jacek (anthropologist and photographer) and IK. 
collects and agreed to show us some. She went out and fetched a big jar (about I2 litres) of dried akacia flowers. The huge jar of bright flowers rolled on the floor of the dim-lit room, looking beautiful and spectacular.

"I'll make a cup of akacia tea for you," said babka Stasia. In the course of preparation, she added other plants to the tea and it turned out that she rarely makes recreational tea from just one herbal ingredient. She kept small, handy supplies of: derevijl tysiachylistnik (Achillea millefolium), miata (Mentha spp.), zveraboi (Hypericum perforatum) in the summer kitchen in plastic bags. They were all kept together, and she took out the inflorescences and flowers as and when she needed. Babka Stasia mentioned that she had drunk the contents of a 3 -litre jar of dried akacia flowers over the course of the winter - a huge amount for one person - but that she still had more than she needed. Like other women in her community, she stockpiles herbs to share them later with friends and family.

We learnt that, unlike other plants, akacia has to be stored in a glass jar. Once dried properly it preserves well, keeping its sweet taste and aroma, and the glass prevents insects from entering the container. It is not by accident that these flowers have an intense, sweet odour and attract animals: it is an important element of their evolutionary role. Mentioning the aroma and taste of the fresh flowers evoked memories of difficult times - of hunger and poverty, both very important to her, and both connected to akacia. Babka Stasia, rather animated, starts to recount:

\footnotetext{
After the War in 1947 there was famine. In some places in Ukraine people starved, in others not. People from our village travelled to western parts of the country to survive and bring something to eat. Bloated people sometimes collapsed, and even died on the village paths. And we, we, my siblings and I, collected akacia flowers. Afterwards, we took the flowers off the stalk. Our mother would grind it to a pulp with a wooden pestle and make bliny [pancakes]. We survived thanks to the weeds, thanks to akacia. In ' 47 we ate only weeds... It is clear that they are healthy, because we were able to survive.
}

She mentioned other plants eaten at that time: polutycia (Convolvulus arvensis), babka (Plantago major) and others, but akacia, as a tasty one, was still of great importance to her. The taste that is attractive to human and non-human animals comes from high contents of amino acids, phytosterol and sugars in the nectar and pollen (Somme et al. 20I6). This plant strongly invests in reproductive organs, producing a large flower crop and valuable nectar resources (Giovanetti 20I8). Flowers are visited and pollinated (in the plant's natural range - the US) by bees (mainly the honeybee - Apis mellifera) and hummingbirds (Huntley 1990). This might be important, because a range of similar plant active compounds are toxic to both honeybees and human beings (cf. Jansen et al. 20I2). This feature allows humans to use the same nectar sources as honeybees use. In contrast, attracting people to eat flowers does not directly influence the reproductive success of akacia, but it may influence the decision to plant this tree. 
Babka Stasia doesn't prepare akacia the way her mother did back in 1947, but instead collects it in abundance and then dries and drinks it, or uses it to make infusions for irrigations or for rinsing the genitals. Akacia is both an edible and a medicinal plant. Babka Stasia has a strong emotional connection with the plant based on a gratitude which stems from the time of famine. Similarly to other village dwellers, she did not stop collecting edible plants after the famine experience (cf. Pirożnikow 20I4).

In the meantime, the water in the kettle was boiling. A handful of akacia and several inflorescences of derevij and zveraboj were taken out of plastic bags and put into a small $(300 \mathrm{ml})$ jar (Fig. I). Babka Stasia poured boiling water onto the herbs. She inhaled loudly and asked: "Can you feel the smell spreading in the kitchen? Each herb has its own scent. Akacia smells like summer, like June in the middle of winter." Smelling was very important to her. She encouraged us to smell all the herbs she showed us.

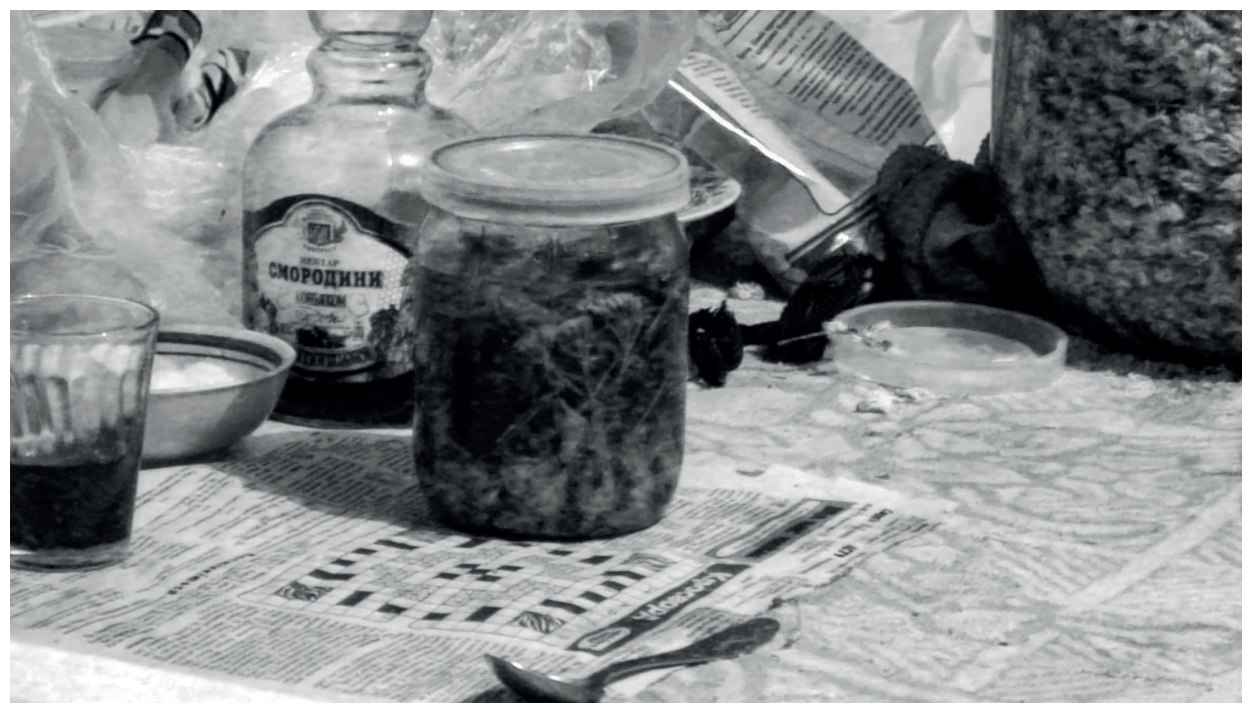

Fig. I. The process of akacia (Robinia pseudoacacia) tea preparation. Podilia, Ukraine. Author: Jacek Wajszczak, 20I3

Akacia flower collection practice is very common in the village, mainly among women. They use it for medicinal purposes (for irrigations and for rinsing the vulva in the case of excessive white vaginal discharge), but also as a recreational tea. Akacia grows in the village in a few places. For babka Stasia, the akacia wood is the main source of akacia flowers because it is remote enough (although still within the village borders) and is not polluted due to car traffic (as local opinion holds). What is more, inflorescences on the wood's edges are easily accessible, even for an elderly person. 
Such woods spread spontaneously and have become a common feature of the Ukrainian forest-steppe (cf. Sytnyk et al. 2016), even though akacia is not a native tree there. Akacia often grows in dense thickets of clones (the wood in the village is such a thicket). Thanks to the root suckers (a vegetative regeneration), an extensive root system and the ability of nitrogen fixation (through cooperation with Rhizobium bacteria), it is well adapted for survival in disturbed areas (Cierjacks et al. 20I3). Thanks to its clonal growth, it readily colonises new areas. This feature increases the potential of R. pseudoacacia for landscape change, also causing other changes, for instance in fauna and flora, animal behaviour, etc. (cf. Buchholz and Kowarik 20r9; Cierjacks et al. 2013; Giovanetti 2018). Human-animal behaviour is also influenced, amongst others because such akacia woods are difficult to pass through. This is mainly due to the large thorns present on younger branches and the density of the undergrowth consisting of young root suckers.

The thorns are mentioned by many village dwellers, but the older generations remember them more vividly than others, as this particular feature of the akacia species poses a threat to bare feet. Nowadays, it is not a problem anymore, as shoes are not that expensive and a universal commodity. Nevertheless, some village dwellers, young boys in particular, still consider the thorns a threat to their bike tires. People rarely enter the wood babka Stasia mentions: instead they usually collect akacia flowers available at its edges. The thorns, a highly unwanted feature from the village dwellers' point of view, play a role in protecting the plant from herbivores (including human beings as shown above). The bioactive compounds present in all parts of the plant (except the flowers), and especially in the bark, may be toxic to human and non-human animals (Stankov et al. 20I8; Tyśkiewicz et al. 2019). Thus, they play a similar role to thorns. Although the active compounds toxic for humans are destroyed by heat (Frohne and Pfänder 1984), all of my interlocutors used only the flowers of akacia as food. Drinking the akacia tea, we continued the meeting.

\section{Edibility in the context of collecting, sharing and microhabitats. Case study form lowland Daghestan.}

The protagonists: human - Aishat (about 55), Mariat (35) and plant - zhibzhnil mokrica, (Stellaria media (L.) Vill.). This case study comes from the research project "Documenting Dargi languages in Daghestan - Shiri and Sanzhi" conducted between 2012 and 2019 in Daghestan - a republic of Russia in the Northern Caucasus - a region characterised by high ethnic and biological diversity. The case was recorded in Druzhba village (lowland Daghestan) in April 2019 and is the result of a walk in the woods with two Dargi women. The Shiri community, who used to live in Shiri - a small village in the mountainous part of Daghestan, the Dakhadeyvskij region - speaks its own Shiri language (one of the Dargi languages). Nowadays, most Shiri people live in multi-ethnic settlements in the lowlands such as the village Druzhba. Druzhba 
is mostly inhabited by Dargi (including Shiri), Tabasaran and Agul ethnic groups. The main language of research was Russian, which is the lingua-franca in Daghestan and is the most common language of communication with people outside the village. Sunni Muslims predominate in the community.

Geographically, Daghestan is characterised by four belts of physio-geographical provinces. Two physiographic belts are important for the case: first, the lowlands by the Caspian sea (where Druzhba village is located) have quite a dry and continental climate with a mean annual temperature of $\mathrm{I} 2.5^{\circ} \mathrm{C}$. Steppe is the prevailing habitat (Matuzaliev 20I6) and industry and large-scale agriculture is also located in the area. Second, the intra-mountain belt (where mountainous villages mentioned in the case study are located) has a mean annual temperature of $6^{\circ} \mathrm{C}$, and a prevalence of species-rich mountainous meadows and mountainous steppe habitats (Matuzaliev 20I6). There are significant differences in flora between these belts (cf. Litvinskaja and Matuzaliev 20I3, IO-I9), which notably influence the collection of wild plants and plant exchange patterns between the dwellers of the belts.

When wes came to visit Aishat (a Dargi woman of Shiri origin), her friend Mariat (a Dargi woman from Urari) was already there. They were planning to go out to collect mokrica, which is one of the leafy greens collected in many parts of Daghestan and beyond (e.g. other parts of Russia and the former USSR). It is often traded at Daghestani markets by members of some ethnic groups (mainly Azeris and Tabasarans). For both our interlocutors, and generally for Shiri people, the leafy greens may only be bartered, but never sold (Kaliszewska and Kołodziejska-Degórska 20I5). Mokrical zhibzhni is used as a filling for chudu (a stuffed pie, also referred to as hullkni) and kurze (dumplings). Generally, wild leafy vegetables are a significant element of everyday social life in Shiri in regard to mutual care, respect for elders and local identity and pride (Kaliszewska and Kołodziejska-Degórska 20I5).

We went together to collect mokrica in the so-called sovkhoz vineyards. ${ }^{6}$ It was the end of March; the temperature in the lowlands, where Druzhba village is located, was around $\mathrm{I}^{\circ} \mathrm{C}$. But in the mountain villages, from which both Aishat (Shiri) and Mariat (Urari) originate, it was snowing. The weather was an important subject in our chat on the way. Mariat stressed that she collected plants all year round, if possible. She told us that that year (2019) she had bestowed her son's teachers with two plastic bags of collected mokrica in January. It is the only leafy green that can be collected all year round in lowland Daghestan - in the mountains, the climate is harsher and there are

5 Iwona Kaliszewska and IK.

6 The name sovkhoz (Soviet state farm (rus. sovetskoye khozyaistvo)) is still used by locals, even though the former sovkhoz was transformed into a private enterprise and the lands belonging to it were sold. 
no such plant species. She hoped that the teachers appreciated the gift, as it was difficult to collect mokrica in winter, because the plants are small and hands go numb in the cold. We understood that mokrica and other self-collected plants have significant informal economic value for her. She may use them in reciprocity practices, giving them not only to the teachers in the periods when it is difficult to get leafy greens, but also exchanging them with family living in the mountains. She is able to gather leafy greens in the lowlands, before the vegetation period in the higher elevated areas starts. So she barters them with her sister in Urari for dairy products and leafy greens typical for the highlands. Leafy greens from the mountains (for the species list of taxa collected by Shiri people, see Kaliszewska and Kołodziejska-Degórska 20I5) are often seen as of better quality and taste. Such opinions concern taxa that are characteristic for the mountains and are not available in the lowlands. Moreover plants coming from the mountains are referred to as ekologicheski chistoe (ecologically clean) (for a broader post-soviet context of the term see, for example, Caldwell 20II, 74-100). Lowlands are seen by our interlocutors as polluted. Such a notion is based on the observation of the presence (now or in the past) of industry and larger-scale agriculture involving the use of agrochemicals and common knowledge of bioaccumulation processes in plants (cf. Reinert 2019). Additionally, this notion is greatly enhanced by the romanticised view of the places in the mountains from which particular communities originated.

Both women took plastic bags and small knives with them to collect the plants. Mariat was wearing a dedicated apron with a big pocket. Mariat was the leader during this expedition: she instructed us, as the less experienced ones, on how to use a knife to dig out and cut the plant, showed all of us (including Aishat) the vineyard rows we should collect in, and instructed all of us that it was the best to gather plants that were not flowering yet. It is usually easy to see a dense, prostrate carpet of infinitely spreading zhibzhni in the soil between the vines. This time it was not so dense, both women noticed. The plant prefers moist soil and a position in full sun or partial shade. In moist conditions, it flowers and sets seeds all year round (Turkington et al. 1980).

Mariat was moving fast through her row. She first placed the plants into her apron, and when it was full she would transfer the load in the plastic bag. When the bags were full, she left them by the vineyard's poles. None of us, including Aishat (a skilled gatherer of other plants), collected as much as Mariat did, or moved with such grace. Mariat told us that she had learned to collect mokrica from her Tabasaran neighbours. She loves plant collection; the actions following plant gathering, such as removing the roots and soil, soaking and chopping, are more tiresome for her and wear her out.

Aishat collected zhibzhni without Mariat's ease, and was a bit puzzled by Mariat's suggestion to collect only not-flowering specimens. It was difficult to find such plants, and at the beginning she not only moved slowly and looked for not flowering plants, 
but also tore off floral shoots. The plant individuals ${ }^{7}$, without flowers, grew on drier microhabitats. Their shoots were a bit reddish and not as watery. Some of them had already fruited, which at first sight may be mistaken for flower buds. They most probably differed in their chemical composition, and the amount of active compounds and vitamins available. For example, in the research of Merritt (1986) on the tolerance of $S$. media to applications of ioxynil octanoate (a herbicide), plants grown under moisture stress contained greater concentrations of the pigments chlorophyll a, carotene and lutein (a xanthophyll) than moist grown plants did. Moreover, significant linkage was found between soil parameters and $S$. media's proteinogenic amino acid (precursors to proteins) content. Garden soil is the most favourable for amino acid content (Dziagwa-Becker et al. 20I6). The preference for mokrica collection in the vineyard is motivated by its availability. Mokrica in the vineyard is easy to spot and collect in the large quantities needed for food supply for families. Additionally, the amino acid content could be higher in cultivated soil.

Both women called zhibzhni a "fat" plant (zhyrna), referring to its watery shoots and nutritional value. Mariat, like Tabasaran women, sees it as a plant full of vitamins, so she finds it especially important to eat it in springtime. It contains such vitamins as: A: 30mg; Thiamine (BI): 0.02mg; Riboflavin (B2): 0.I4mg; Niacin: 0.5Img; C: 375mg (PFAF, Lanska and Zilak 1992). Zhibzhni leaves contain active compounds, such as saponins, that play an important role for plants as allelochemicals, and in protection from herbivory (by mammals (Tava et al 2000, 45), and insects (Harmatha 2000, 138), fungi and microbes (Osbourn et al. 2000, I22)). The potential of these substances is used by humans in medicine (e.g. Mahato 2000), but in large quantities they can be harmful for people. That is why the procedures of food preparation of plants containing high amounts of saponins are so important, as they are broken down through cooking (Rao and Gurfinkel 200o). The undesirable properties of the water-soluble saponins can be neutralised by soaking the plants. In Druzhba, zhibzhni, when prepared for chudu or kurze filling, is first soaked, and then cooked. In the village, the plant is used as a healthy food (or a functional food in ethnobiological jargon), and is not known for its direct medicinal applications. Furthermore, it is absent from popular books on medicinal plants in the former USSR, such as Popov 1969; Gammerman and Grom 1976; Ivanov 1992, etc.

Both women knew that $z h i b z h n i$ is considered a weed - a plant not wanted in the cropland. Nevertheless, for them, especially for Mariat, it is a valuable, edible plant. In the spring, sovkhoz vineyards are full of women collecting mokrica and other edible

7 Here understood as a grouping of shoots looking like an individual above ground: genetic variation and underground root connections are not taken into account. The definition of an individual in plants is much more difficult than in mammals. In Ioo $\mathrm{g}$ of leaves and shoots. 
greens. Most of them are of Tabasaran origin. It is common to hear members of other ethnic groups referring to Tabasarans as having vast knowledge of plants and "eating everything that is green."

When all the plastic bags brought to the site were almost full, the women decided that we should finish collecting (Fig. 2) and we went back to the village.

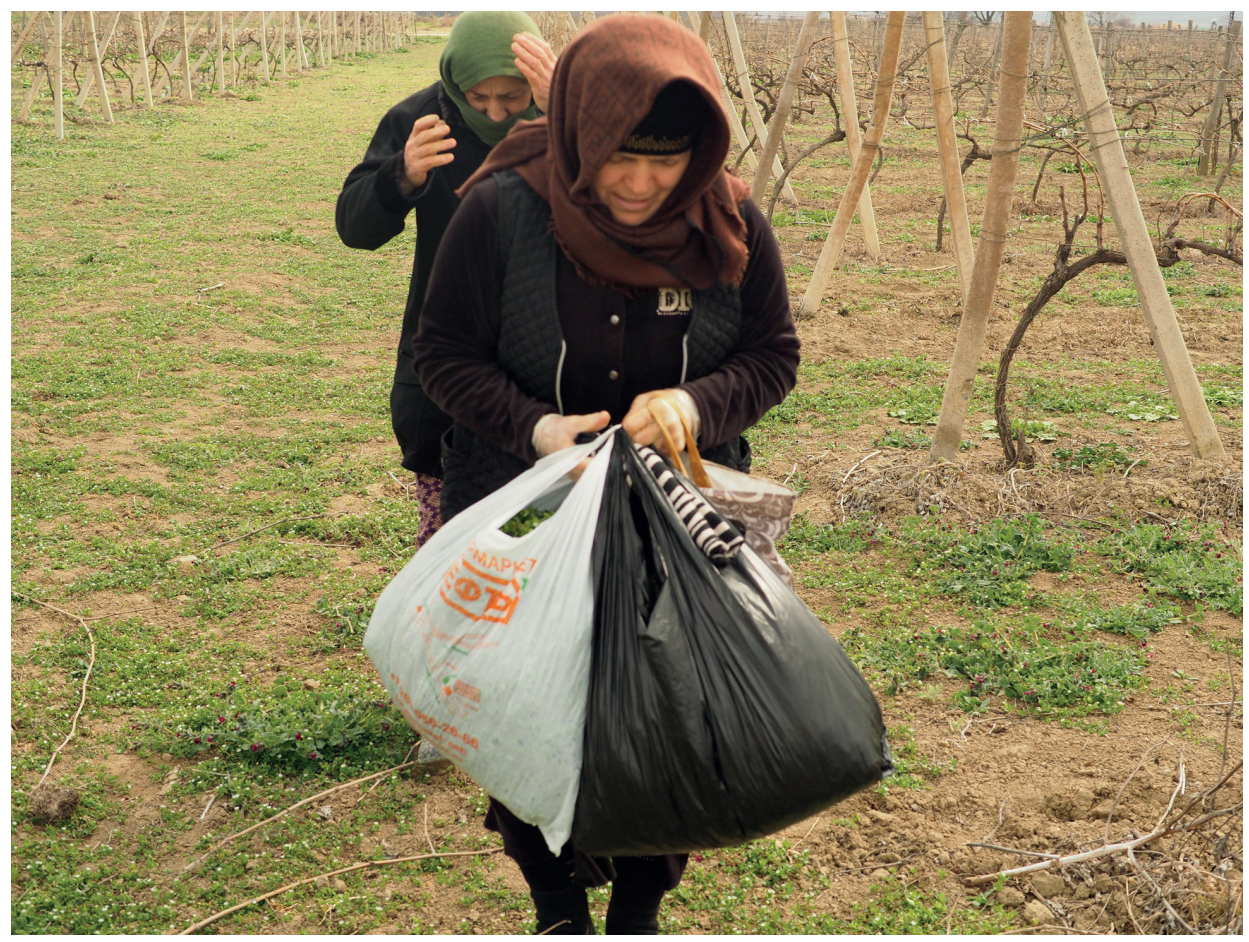

Fig. 2. The women with plastic bags full of mokrica (Stellaria media), after foraging in the vineyard. Lowland Daghestan. Author: Iwona Kaliszewska, 2019.

\section{Interactions of different migrant groups in the Atlantic Forest with the Myrtaceae species}

Between 2007 and 2019, I (MK) worked with two groups in Misiones, Argentina: overseas migrants from central-east Europe and their descendants born in Argentina or Brazil, and with mestizo people who hailed from the same ecoregion as Misiones in Paraguay. For centuries, Misiones has been home to Guaraní indigenous people (Bartolomé M. 2009). During the $19^{\text {th }}$ century, Paraguayan mestizos would visit this region for selective logging and yerba mate extraction. In the $20^{\text {th }}$ century, Paraguayans came to settle in Misiones, due to economic and political push factors (civil war and 
the long period of the dictatorship of Alfredo Stroessner). Between the end of the $19^{\text {th }}$ century and the beginning of WWII, Misiones also witnessed a massive migration of European farmers and peasants, who hailed from temperate climes and settled in this subtropical region to dedicate themselves to subsistence agriculture, the cultivation of cash crops, such as yerba mate, tea, tobacco and pine forests, and/or cattle rearing (Bartolomé L. 1982; Bartolomé and Schiavoni 2008).

The study participants live in mixed ethnic settlements in the western part of Misiones along the Paraná River, the border with Paraguay. However, some of these settlements were established by European migrants, such as Wanda town and Lanusse village (Poles), Puerto Esperanza (Germans) and Ruíz de Montoya (Swiss). Overall, I worked with people of Polish, Czech, Slovenian, Ukrainian, Russian, German and Swiss origins, fully or part time engaged in agriculture, and with Paraguayan mestizo people (locally called criollos). The latter are comprised mostly of small farmers who farm on I-2 ha. plots, with the men also finding employment in the forestry industry. Paraguayan people are bilingual - they speak Spanish and Guaraní.

Phytogeographically, Misiones belongs to the Atlantic Forest of the Upper Paranáa subtropical humid forest (Campanello et al. 2009). Currently, nearly $40 \%$ of original forest cover is preserved in Argentina, in contrast to Brazil and Paraguay, where it comprises approximately 8\% (Galindo-Leal and Câmara 2003). The progressive reduction of the forest surface has occurred due to the expansion of the agriculture frontier, animal husbandry and the logging of native tree species. Nevertheless, the Atlantic Forest still remains one of the most diverse ecosystems in the world (Da Ponte et al. 20I7).

\section{The encounters of Myrtaceae trees and people via fruit edibility}

In the Atlantic Forest of the Upper Paraná, a large diversity of Myrtaceae shrubs and trees grow (Flora del Conosur 2020). Local indigenous and non-indigenous populations have explored the edible and medicinal properties of Myrtaceae fruits and leaves (Begossi, Hanazaki and Tamashiro 2002; Kujawska and Łuczaj 2015; Martinez-Crovetto 1968; Montenegro I710; Schmeda-Hirchmann 1988). According to my records, European and Paraguayan migrants distinguish, name and use is different species of Myrtaceae (see Table I). Fruits are edible to both humans and animals, and birds make a decisive contribution to their dispersion. The consumption of these fruits has been connected by interlocutors to childhood escapades of forest exploration and to family excursions and picnics on stream shores during hot springtime weekends. Men would consume these fruits on an opportunistic basis during work in the forest whenever they found them and, if abundance allowed, bring some back home to share with the family. The species discussed here bear fruits just once a year, in a relatively short period during the spring and early summer (October-December). But there exists some variability in this pattern due to variation in microhabitats, such as sun exposure, vicinity of a water body, etc. What is interesting in these narratives is the 
conjuncture of the consumption context (adventure, strolling, picnic, work-break) and the relatively short period of foraging. It seems that there is little space for an unexpected encounter. Initial random encounters with Myrtaceae fruit trees and shrubs often happened as an outcome of wayfaring and forest exploration, but subsequently the trees were remembered and incorporated into embodied maps. Moreover, people exchanged information about the edible fruit bearing trees, adding more points to their maps. They also learned the ecology of Myrtaceae trees, so they were able to expect where to find them.

Enjoying the natural abundance of Myrtaceae fruits is not the only possibility the local people have and explore. Encouraged by the trees' versatile properties, their easy growth from seedlings and the pleasant scent of their flowers, some European and Paraguayan migrants started to propagate these trees by protecting them at their natural sites, transplanting them and sowing the seeds of preferred species in home gardens, pastures and agricultural fields. It is difficult to state when this process started, as migrants have settled in Misiones from the end of the $19^{\text {th }}$ century arriving in different migratory waves, and the process of selecting and manipulating Myrtaceae species can be observed to this day. These practices imply two processes: in situ conservation and incipient domestication. The latter involves the conscious planting of selected seedlings which come from big fleshy fruits, so that these features can be manifested in further generations. Such incipiently domesticated plants have relatively low phenotypic and genetic differentiation compared to their wild relatives (Clements I999; Lins Neto et al. 20I4).

The names of different species of Myrtaceae originate from Guaraní, Spanish and Portuguese, but also from German and Polish. Some of the Guaraní names recorded in this study had already been mentioned in Materia Médica Misionera attributed to a Jesuit monk, Pedro Montenegro (I7IO). Yva hai (Eugenia pyriformis) is a Guaraní name that means "sour fruit". European migrants have adopted this name, sometimes pronouncing it as ubahai. German migrants, however, have invented their own name saurer Apfel meaning "sour apple" - taking an apple as the prototype fruit, but placing the taste characteristic - sourness - in its name as the Paraguayans had done. The above-mentioned German name, or the Polish name for Eugenia involucrata cerella-dzika czereśnia, "wild cherry", were invented at a time when European migrants had had little contact with mestizo and Guaraní people, so they made up names based on different associations, in order to communicate and pass on knowledge. This was an important step in becoming familiarised with the local flora of Misiones.

When asked about the motivation for foraging for wild Myrtaceae fruits, interlocutors' answers were recurrent: the sensual pleasure - the scent of the fruits (they contain essential oils), their unique and complex taste: sweet and sour at the same time. Some fruits of Myrtaceae contain tannins (Campomanesia xanthocarpa, Eugenia uniflora) or saponins (Psidium guajava), which make them astringent (Silva et al. 2006). Hence, it is not only the sugars - the direct product of photosynthesis, but 
also the allelochemicals present in fruits, which makes their taste and smell so attractive to people, and that makes them safe too when consumed in moderation. Another reason for consuming these wild fruits were the positive memories triggered through their smell and taste. On occasions, study participants would compare pitanga, yva hai or guavira with fruits available in grocery shops, and would contrast the complex taste of the former with the blunt sweetness of fully domesticated market fruits. Myrtaceae fruits are consumed on the spot as raw snacks, a practice due both to the context of consumption and to the scent of the fruits which is lost after some time (volatile oils evaporate). Some descendants of European migrants prepare homemade wine from pitanga, cerella and yaboticaba (Fig. 3). This practice seem being influenced by the tradition of making preserves for wintertime and a wide expertise in homemade fermentation (Łuczaj 20IO), brought from their countries of origin.

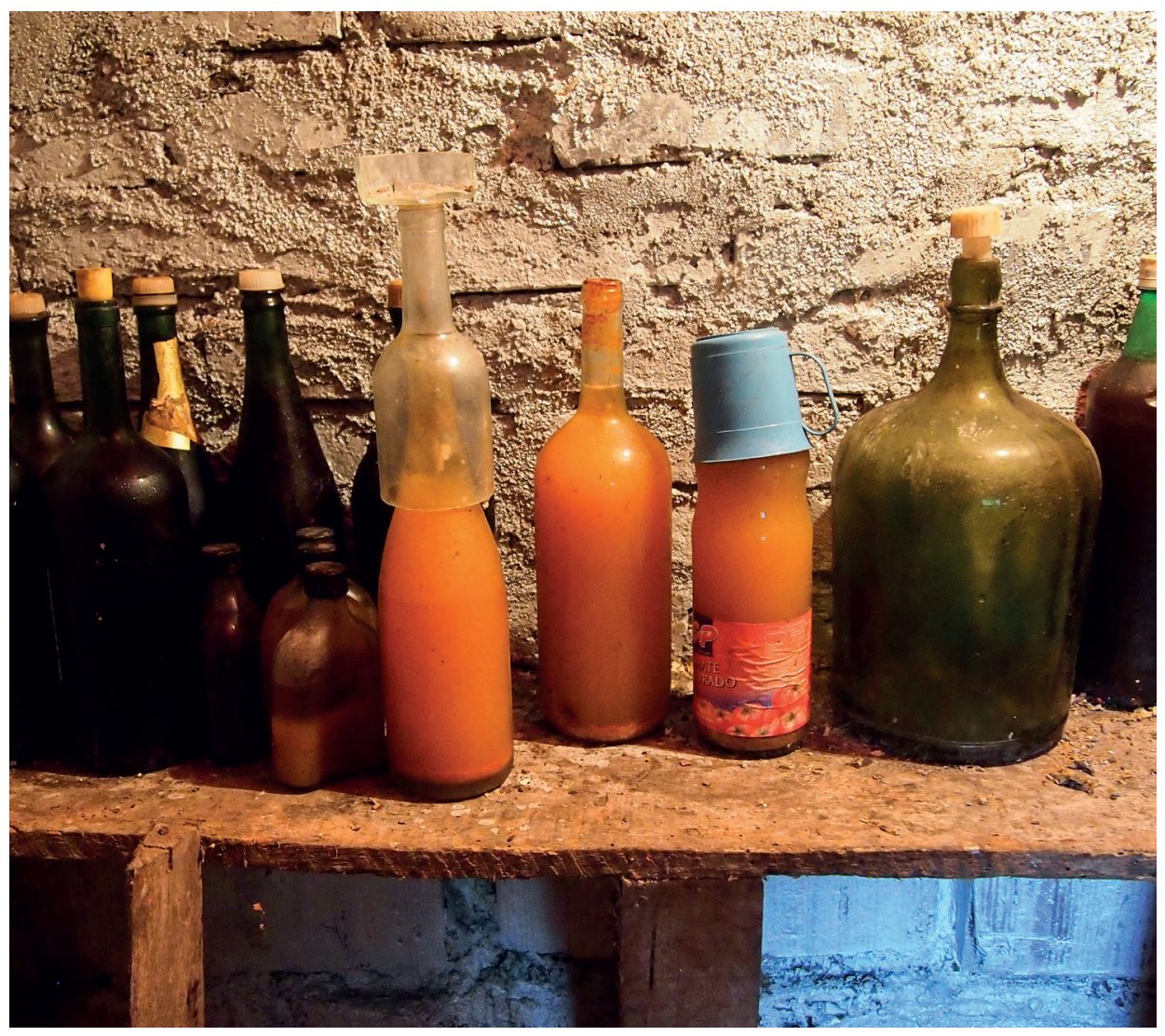

Fig. 3. Homemade wine from the fruit of pitanga (Eugenia uniflora) made by a descendant of German migrants in Misiones, Argentina. Author: Monika Kujawska 2014. 


\section{The encounters of Myrtaceae trees and people via the pharmacological action of leaf and bark}

The fruits of some Myrtaceae species have a medicinal value, due to the tannins, saponins, flavonoids and essential oils they contain (Pin and Céspedes 2009). However, apart from Plinia trunciflora, whose dried fruit skins (exocarps) are used as a remedy against diarrhoea, and Eugenia pyriformis, whose fruits are ingested against diabetes, no other fruit has been mentioned as being used as a food medicine (Fig. 4). Food medicine is defined here as food plants and products ingested for a specific healing purpose (Etkin 1993). Instead, we can observe a pattern in which the fruits of

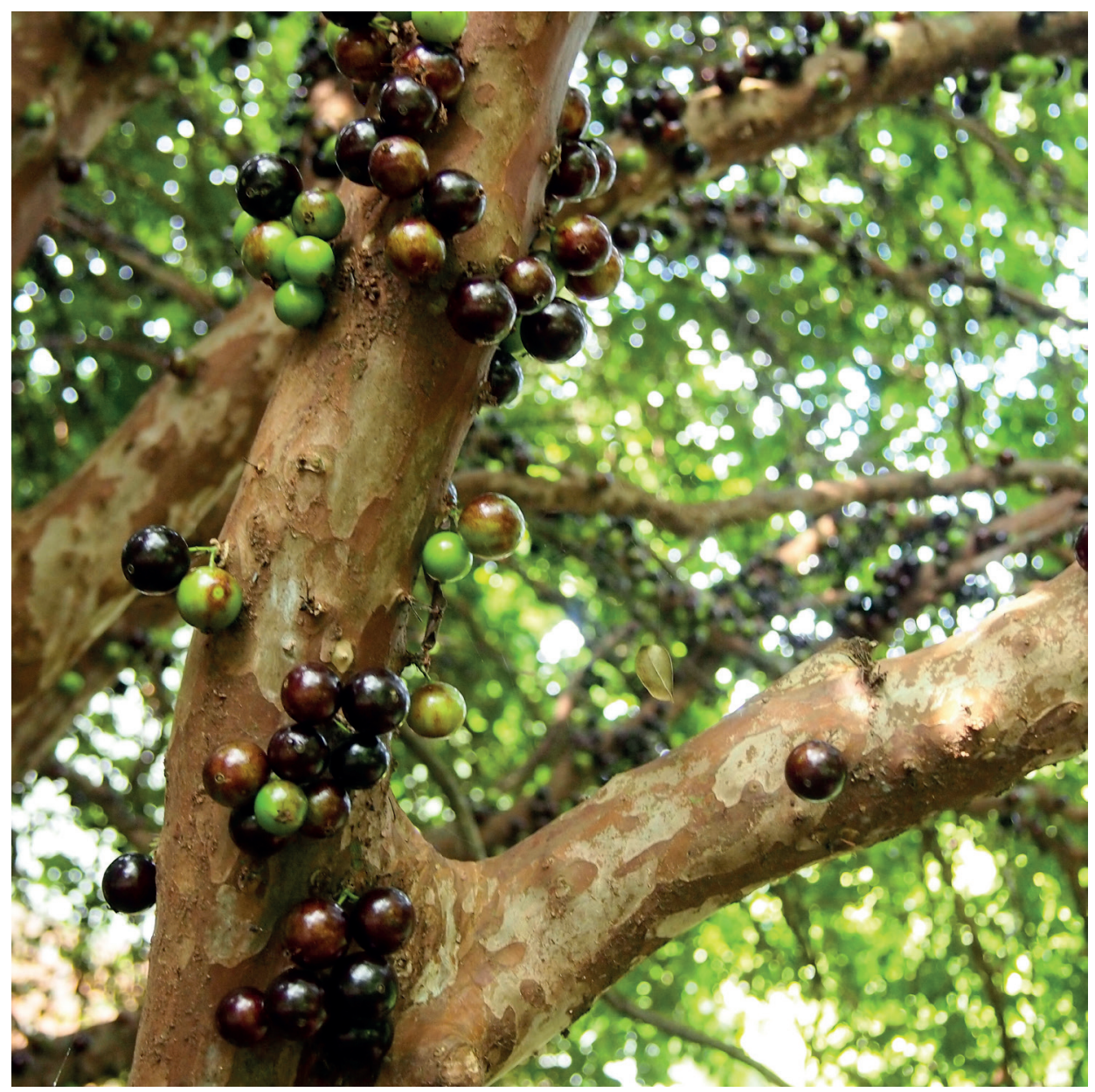

$\oplus$

Fig. 4. Yaboticaba (Plinia trunciflora) tree grown in a home garden of Polish descendants in Misiones, Argentina. Author: Monika Kujawska 2015. 
Myrtaceae are ingested in a food context, and the leaves and bark are used as medicine and for hygiene (see Kujawska and Pieroni 20I5; Kujawska 20I8). This discrete use of fruits and leaves has its explanation in plant chemical ecology. In the medicinal context, the leaves or bark of different species of Myrtaceae are used predominantly in cases of diarrhoea. Moreover, the leaves of Eugenia uniflora are widely used in yerba mate infusions against hypertension. As a result of phytochemical assays, this species has been assigned hypotensive activity (Auricchio and Bacchi 2003). Campomanesia xanthocarpa is also used to combat bad smelling feet - the allelochemicals are absorbed transdermally (for more examples, see Table I). Nina Etkin (1993) has observed that multiple uses of certain plants increases people's exposure to the chemically active compounds in these plants. Thus, multiple and multicontextual ingestion of fruits in a food context and leaves or bark in medicinal infusions increases the potential of exposing the dwellers of the Atlantic Forest to active substances found in Myrtaceae plants.

\section{DISCUSSION AND CONCLUSION}

In this paper, we brought together three different cases of people-plant relationships, viewed from a human foraging, food processing and edibility perspective. They clearly show that plant consumption and the ingestion of certain chemically active constituents take place in an environment specific context of dwelling. Not all plants in the environment are treated equally by humans, and people-plant entanglements may be anchored in plant utility. The utility of a particular plant derives from the vast ecological relations the plant has with other organisms dwelling in the same environment. It is important to note that most of the plant features that people find utile have not co-evolved only in interaction with people, but rather with other non-human organisms. The people-plant entanglement, even if deeply immersed in utility, enhances peoples' insight into plant ecology and plants' needs. Co-dwelling in the same environment with plants and paying attention to certain species through their edibility, stimulates people's enskillment. Our examples indicate that plant utility may be multicontextual and multidimensional, and not necessarily reduced to a commodity level. Within foraging practices not only are skills acquired, but also emotional bonds are created, such as thanksgiving to the akacia for helping to survive famine, showing care for relatives through mokrica or the moments of relaxation accompanied by Myrtaceae fruits.

Our choices and directions in telling the story about plant-people interrelations are certainly informed by our methodological choices and our background (both anthropological and in the natural sciences). Our cases are the results of a temporary co-dwelling with our interlocutors and learning with them the way they interact with 
plants. The composition of the cases enables our interlocutors partly to speak for themselves, and the use of the languages of ecology and chemical ecology allows us, although in a limited way, to speak for the plants. The language of ecology does not go against the dwelling perspective, as one might have perhaps thought, because the relations and the ways through which organisms co-create their environments are the very essence of ecology. The existing intellectual division in academia between natural sciences and the humanities rests on Cartesian foundations. As Ingold rightly points out, "the only way to understand our creative involvement in the world is by taking ourselves out of it" [in terms of the dichotomies emerging from Cartesian dualism] (Ingold 2000, 173). This is why we have used ecologically grounded language in our analysis. Moreover, there are a few disciplines, including critical plant studies, that have emerged within the posthuman or nonhuman debate in the fields of critical posthumanities and feminist new materialism(s) that pay attention to the chemical aspects of plant communication and interspecies interactions (for example, in the works of such authors as: Donna Haraway, Michael Pollan, Stacy Alaimo, Carla Hustak and Natasha Myers).

Concentrating in the case studies on one plant taxon or an ethnotaxon is used as an explicit and direct way to operationalise the concept of the edibility approach. At first sight, the proportions seem unequal: we rarely describe one human actor as the counterpart to one plant taxon. Rather, we usually take into account many human narratives, multi-human standpoints, their background, age, gender, etc. But, indeed, here we do not write about a single plant, one exemplar, but about a population of plants of a certain species (or a family, in the case of the Myrtaceae). In similar fashion, in varying the number of human actors we depict in the particular cases, we aim to write about the relations between a certain population or a local group of Homo sapiens and the plants in question. The Ukrainian and Daghestani cases pay attention both to detail, as manifested in descriptions of movements in the environment and through references to sense and psycho-physical states, while also addressing broader social context. A more synthetic description of the interactions with Myrtaceae allows, on the one hand, a description of a greater number of plant protagonists and plant-human co-evolutionary processes (incipient domestication), but on the other elides individual human motivations and interactions with plants. These two modes of writing ethnographies, in which both people and plants are protagonists, strengthen the operational possibilities of implementing the above-proposed concepts and thus enable theoretical contributions (Goodenough 2004).

Paraphrasing Ingold (2000), although plants dwelling in environments work hard on the construction of their environment, nevertheless being tied with roots to a particular place, they rely on the physicochemical parameters of soil that are crucial for nutrient availability (Dziagewa-Becker 2016). The composition and quality of the microhabitat that a particular plant or a plant population grows in and co-creates 
influences the plants' chemical composition (e.g. Hayati and Proctor 1990). Moreover, changes in the amount of some plant metabolites indicate response to environmental conditions and stress. Such factors, as shown in the case study from Daghestan, can guide people's choices of the particular plant individuals to be collected. The reason for this is that some of the differences in the chemical composition of plants are visible in their morphological features, as perceived by interlocutors and used by them as predictors of taste. The ability to notice these predictors forms a part of enskillment processes resulting from dwelling in a particular landscape (Ingold 2000). Dwelling results in an attunement to temporality, which is illustrated by the Atlantic Forest dwellers' knowledge of plant phenology: an experiential knowledge regarding where and when they can find fruits of particular Myrtaceae species. As a consequence of observing the plants in their environment, which is a multi-sensual task, they notice and stress the correlation between sun-exposure of fruits and their taste. Moreover, the taste and its temporality (the volatile nature of scent) plays a crucial role in the process of planting Myrtaceae trees in their gardens. The fact that the compounds responsible for floral scents have a volatile nature influences the behaviour of women collecting akacia. Those who are experienced harvesters know that it is better to preserve dried akacia flowers in glass jars than in plastic bags or air ventilated sacks. Additionally, the interaction with other non-human animals is taken into account, because dried yet still sweet flowers attract insects. Volatile compounds have a communicational role in ecological relations and people receive the messages, or just some parts of messages, addressed to various co-dwellers of a particular environment (Karben, Shiojiri, Ishizaki 20II).

The sessile nature of plants is closely related to the trait of a distribution of chemical compounds. Concurrently this feature of plants implies that when people perceive some plants as edible, they tend to propagate them, i.e. move them towards people's households. People's foraging practices are also related to the sedentary nature of plants, either through wayfaring in the environment in search of plants, or through moving from one place to another according to an embodied resource map, or a combination of these two. People actively nurture plants using different methods and techniques (toleration, protection, cultivation), plants on the other hand nurture humans when they are ingested and contribute to vital processes in human organisms.

Along with the importance of taste and individual nourishment in the shaping of the foraging practices in our study sites, it is worth mentioning social-body nourishment (Daly 2019). In Podilia, the gathering and consumption of wild plants is not only an everyday practice, but a part of a national identity discourse (Kołodziejska-Degórska 20I6). As shown in the Daghestani case, people compare the flora of wild plants gathered by various ethnic communities. Wild edible plants from the mountainous villages are markers of local identity for the Shiri community (Kaliszewska and Kołodziejska-Degórska 20I5). The wild edibles are seen as valuable enough to 
circulate between localities in the lowlands and the mountains, as well as to be exchanged for goods or favours. In such a way, relations in the human community are maintained thanks to non-human actors (for more on the role of food circulation in the reproduction of social relations within communities in Daghestan, see Kaliszewska 20I8). These practices emerge from humans not plants, but the EA argues that agency is a distributed force and not something that only resides in people.

According to Ingold's dwelling perspective, "the landscape is constituted as an enduring record of - and a testimony to - the lives and works of past generations who have dwelt within it, and in so doing, have left there something of themselves" (Ingold 2000, 189). Although Ingold refers in his work to animals (human and non-human), we argue that generations of plants who have dwelt within the landscape have also left something of themselves, for example generations of akacia (co-existing with Rhizobium bacteria) leave soil with higher nitrogen content. Akacia is a special agent of change in an environment which the tree shares with other organisms, influencing the foraging behaviours of animals, including humans (e.g. through thorns, soil nitrogen enrichment dense thickets, chemical composition of nectar). People dwelling in the Atlantic Forest with native Myrtaceae spp. result in their propagation (the effect of agency of both plants and "their people"), through processes which could be seen as leaving footprints in the forest, to paraphrase William Balée (1994). Historical ecology in the Atlantic Forest and Amazonia has shown that inhabited environments are most often testimonies of the agricultural activity of previous generations of agriculturalists (horticulturalists) or other groups (Balée 2013). European and Paraguayan migrants who arrived en masse in Misiones stood on the land (landscape) co-created by the Guaraní. These newcomers (or intruders, for the Guaraní), found Myrtaceae fruits which were part of the Guaraní legacy, an outcome of their long-lasting interactions with the environment (Montenegro I7IO; Martinez-Crovetto 1968). One event of ingestion of Myrtaceae fruits did not provoke a craving for these plants on the part of European migrants - such a "eureka" effect produced by a single ingestion is more likely to be seen in cartoons. It was rather a long process which involved living with, as well as learning about and sensing (smelling, tasting) Myrtaceae fruits.

Some elements of chemical ecology can be helpful in explaining aspects of food preference, food processing and plant propagation from our cases. Humans, through taste and smell, may detect many different chemical substances, which act either as stimulants (attractants) or deterrents (repellents). Fruits of Myrtaceae act as attractants to both human and non-human animals through their sweetness and the pleasant scent of volatile oils. Perception of such stimuli depends on neurophysiological responses, but also on the interpretation of the stimuli. The sweetness of Myrtaceae is certainly above the threshold level for perceiving it, but with sweetness come other tastes and flavours: allelochemicals, which have not been eliminated through different techniques of plant protection and propagation. Humans' taste preferences are, here, 
one of the factors creating an environment of domestication (Leach 2003). A vast number of chemicals cannot be detected by humans through their taste or scent. Mokrica (Stellaria media) is neutral in its taste and the saponins found in it cannot be detected and determined as deterrents. Thus, Shiri people have developed (or borrowed) a technique to eliminate saponins from the plant by soaking it in cold water, a practice that at the first sight may look just like a cleaning process. This example demonstrates how plant chemical constituents can lead to culturally specific human techniques of food preparation.

In this paper, we aimed to show that in order to realise the postulates of the edibility approach, an engagement in both practical and theoretical imagination (understood after Willis 2000) cannot be restricted only to people's everyday lives, experiences, conditions and practices, but should also be extended to those of non-human organisms. We personally see the tools of ecology and chemical ecology as those most complementary to ethnographic ones in helping to achieve this goal. Our recommendation is to build stronger and more insightful collaboration between ethnographers and ecologists.

\section{ACKNOWLEDGEMENTS}

The article was written as a part of a project financed by the National Science Centre nr 2018/31/B/

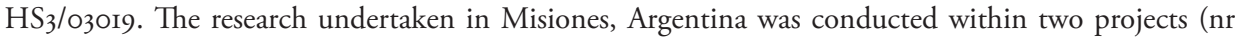
20I8/31/B/HS3/03019; 2013/09/N/HS3/02226). The case study from Ukraine was supported by National Science Grant nr 20II/oI/N/HS3/o3332, and the case study from Daghestan was supported by the Volkswagen Foundation project: "Documenting Dargi Languages in Daghestan: Shiri and Sanzhi”. MK is grateful to the study participants for generously sharing their knowledge, and to Magdalena Zamorska and Miguel Alexiades for useful references. IK is deeply grateful to all the research participants (especially the protagonists of the cases presented) and to Iwona Kaliszewska for insightful comments on the Daghestani part of the article.

\section{REFERENCES}

Auricchio, M.T., and E.M. Bacchi. 2003. Eugenia uniflora L. "Brazilian cherry' leaves: pharmacobotanical, chemical and pharmacological properties." Revista do Instituto Adolfo Lutz 62, 55-6I.

Attala, Luci. 2017. "The edibility approach': using edibility to explore relationships, plant agency, and the porosity of species boundaries." Advances in Anthropology 7, I25-I45.

Attala, Luci. 2019. "I am Apple': relationships of the flesh. Exploring the corporeal entanglements of eating plants in the Amazon." In Body Matters. Exploring the Materiality of the Human Body, edited by Luci Attala and Louise Steel, Cardiff: UWP, preprint (available at: https://www.researchgate.net/publication/321997248_I_eat_Apple, accessed 27.07.2020).

Balée, William. 1994. Footprints of the Forest: Ka'apor Ethnobotany — the Historical Ecology of Plant Utilization by an Amazonian People. New York: Columbia University Press. 
Balée, William. 2013. Cultural Forests of the Amazon: A Historical Ecology of People and their Landscapes. Tuscaloosa: University of Alabama Press.

Bartolomé, Miguel Alberto. 2009. Parientes de la selva. Los guaraníes mbya de la Argentina. Asunción: CEADUC.

Bartolomé, Leopoldo J. 1982. Colonias y colonizadores en Misiones. Instituto de Investigación. Posadas (Argentina): Facultad de Humanidades y Ciencias Sociales, Universidad Nacional de Misiones.

Bartolomé, Leopoldo J., and Gabriela Schiavoni, eds. 2008. Desarrollo y estudios rurales en Misiones. Buenos Aires: CICCUS.

Begossi, Alpina, and Natalia Hanazaki, Jorge Tamashiro Y. 2002. "Medicinal Plants in the Atlantic Forest (Brazil): Knowledge, Use and Conservation." Human Ecology 30 (3), 28I-299.

Bohn, Udo, and Gisela Gollub, Christoph Hettwer, Zdenka Neuhäuslová, Thomas Raus, Heinz Schlüter, Herbert Weber, eds. 2004. Map of the Natural Vegetation of Europe. Scale I : 2500 ooo. Münster: Landwirtschaftsverlag.

Buchholz, Sascha, and Ingo Kowarik. 2019. Urbanisation modulates plant-pollinator interactions in invasive vs. native plant species. Scientific Reports 9 (6375), I-9.

Bulayeva, Kazima B., and Elizabeth Marchani, Olga L. Kurbatova, Scott W. Watkins, Oleg A. Bulayev, Henry C. Harpending. 2008. "Genetic bottleneck among Daghestan highlanders migrating to lowlands." Central European Journal of Medicine 3, 396-405.

Caldwell, Melissa L. 20Ir. Dacha Idylls Living Organically in Russia's Countryside. Berkeley, Los Angeles, London: University of California Press.

Campanello, Paula I., and Lía Montti, Patricio Mac Donagh, Guillermo Goldstein. 2009. "Reduced impact logging and post-harvesting forest management. Alternative approaches to enhance canopy tree growth and regeneration and to reduce the impact of invasive species." In Forest Management, edited by S.P. Grossberg, 39-59, New York: Nova Science Publisher.

Cierjacks, Arne, and Ingo Kowarik, Jasmin Joshi, Stefan Hempel, Michael Ristow, Moritz von der Lippe, Ewald Weber. 20I3. "Biological Flora of the British Isles: Robinia pseudoacacia." Journal of Ecology IOI, I623-I640.

Clements, Charles R. 1999. "I492 and the loss of Amazonian crop genetic resources I. The relation between domestication and human population decline." Economic Botany 53 (2), I88-202.

Da Ponte, Emmanuel, and Marthe Roch, Patrick Leinenkugel, Stefan Dech, Claudia Kuenzer. 2017. "Paraguay's Atlantic Forest cover loss - Satellite-based change detection and fragmentation analysis between 2003 and 2013." Applied Geography 79, 37-49.

Daly, Lewis. 2019. "The nature of sweetness: an indigenous fermentation complex in Amazonian Guyana." In Alcohol and Humans: A Long and Social History, edited by Kimberley Hockings and Robin Dunbar, 130-I46, Oxford: Oxford University Press.

Daly, Lewis, and Katherine French, Theresa L. Miller, Luiseach Nic Eoin. 20I6. "Integrating ontology into ethnobotanical research." Journal of Ethnobiology 36 (I), I-9.

Dziągwa-Becker, Magdalena M., and Olga Kalitowska, Wiesław A. Oleszek. 2016. "Influence of selected soil parameters on amino acid profile in Stellaria media." Polish Journal of Agronomy 27, 32-37.

Etkin, Nina L. 1993. "Ethnopharmacologic perspectives on diet and medicine in Northern Nigeria." Actes du 2 Colloque Européen d'Ethnopharmacologie et de la II Conférence Internationale d'Ethnomédicine, Heidelberg 24-27 mars 1993, 58-62.

Flora del Conosur. Instituto de Botánica Darwinion 2020. http://www.darwin.edu.ar/proyectos/floraargentina/fa.htm (accessed 20.03.2020).

Frohne, Dietrich, and Hans J. Pfänder. 1984. A Colour Atlas of Poisonous Plants. London: Wolfe.

Gabriel, Cynthia. 2005. "Healthy Russian Food is Not-for-Profit." Michigan Discussions in Anthropology special issue Subsistence and Sustenance I5 (I), I83-222. 
Galindo-Leal, Carlos, and Gusmão I. de Cãmara. 2003. "Atlantic Forest hotspot status: an overview." In The Atlantic Forest of South América: Biodiversity Status, Threats, and Outlook, edited by Carlos Galindo-Leal and I. de Cấmara Gusmão, 3-II, Washington DC: Island Press.

Gammerman, Adel F., and Ivan I. Grom. 1976. Dikorastushchie lekarstvennye rasteniia SSSR. Moskva: Izdatelstvo "Medicina".

Giovanetti, Manuela. 2018. "Foraging choices balanced between resource abundance and handling concerns: how the honeybee, Apis mellifera, select the flowers of Robinia pseudoacacia." Bulletin of Entomological Research I09, I-9.

Goodenough, Ward H. 2004. "W poszukiwaniu roboczej teorii kultury." In Badanie kultury. Elementy teorii antropologicznej. Kontynuacje, edited by Marian Kempny and Ewa Nowicka, Ioo-II6, Warszawa: PWN.

Grivetti, Louis E. 2006. "Edible wild plants as food and as medicine: reflections on thirty years of fieldwork." In Eating and Healing: Traditional Food as Medicine, edited by Andrea Pieroni, Lisa L. Price, II-39, New York: Haworth Press.

Haraway, Donna. 2008. When Species Meet. Minneapolis: University of Minnesota Press.

Harmatha, Juraj. 2000. "Chemo-Ecological role of spirostanol saponins in the interaction between plants and insects." In Saponins in Food, Feedstuffs and Medicinal Plants, edited by Wiesław Oleszek and Andrew Marston, I29-I4I, Dordrecht: Kluwer Academic Publishers.

Hayati, Attayeb, and Michael Proctor. 1990. Plant distribution in relation to mineral nutrient availability and uptake on a wet-heath site in South-West England. Journal of Ecology 78 (I), I34-I5I.

Holbraad, Martin, and Morten A. Pedersen, 20I4. "The politics of ontology. Editors' forum. Theorizing the contemporary." Cultural Anthropology, https://culanth.org/fieldsights/series/the-politics-of-ontology (accessed 21.03.2020).

Huntley, Jimmy C. 1990. "Robinia pseudoacacia L. black locust." In Silvics of North America. Volume 2. Hardwoods. Agric. Handb. 654, edited by Russel M. Burns and Barbara H. Honkala, 755-76I, Washington: Department of Agriculture, Forest Service.

Ingold, Tim. 200o. The Perception of the Environment: Essays on Livelihood, Dwelling and Skill. London and New York: Routledge.

Ingold, Tim. 20II. Being Alive: Essays on Movement Knowledge and Description. Abingdon and New York: Routledge.

Ivanov, Vitalij I. 1992. Lekarstvennye sredstva v narodnoj medicine. Moscow: Voennoe izdatelstvo.

Jansen, Suze, and Iris Kleerekooper, Zonne Hofman, Isabelle Kappen, Anna Stary-Weinzinger, Marcel van der Heyden. 2012. "Grayanotoxin poisoning: 'Mad Honey Disease' and beyond. Cardiovascular Toxicology $\mathrm{I2}$ (3), 208-213.

Johns, Timothy. 1990. With Bitter Herbs They Shall Eat It: Chemical Ecology and the Origins of Human Diet and Medicine. Tucson: University of Arizona Press.

Johns, Timothy. 1994. "Ambivalence to the palatability factors in wild food plants." In Eating on the Wild Side. The Pharmacologic, Ecologic and Social Implications of Using Noncultigens, edited by Nina L. Etkin, 46-6I, Tucson: The University of Arizona Press.

Kaliszewska, Iwona. 2018. "Cheese bribe. Viewing social changes through food and mobility in Daghestan, North Caucasus." Sociological Studies 4 (23I) [without pagination] https://doi.org/I0.24425/I22485.

Kaliszewska, Iwona, and Iwona Kołodziejska-Degórska. 2015. "The social context of wild leafy vegetables uses in Shiri, Daghestan." Journal of Ethnobiology and Ethnomedicine II (63) [without pagination] https://doi.org/IO.II86/sI3002-0I5-0047-x.

Karban, Richard, Kaori Shiojiri, Satomi Ishizaki. 20II. "Plant communication - why should plants emit volatile cues?" Journal of Plant Interactions 6, 8I-84.

Kirksey, Eben, ed. 20I4. The Multispecies Salon. Durham \& London: Duke University Press. 
Klaser, Cheng Diana M. 2017. "Phytochemistry." In Ethnobotany: A phytochemical perspective, edited by Barbara M. Schmidt and Diana M. Klaser Cheng, III-I4O, New York: Wiley Blackwell.

Kohn, Eduardo. 2013. How Forests Think. Towards an Anthropology Beyond the Human. Berkeley: University of California Press.

Kołodziejska-Degórska, Iwona. 2016. "Patients' webs of relations in the medical landscapes of Central Ukraine." Anthropology \& Medicine 23 (2), I55-171.

Kujawska, Monika. 20I8. "Yerba mate (Ilex paraguariensis) beverage. Nutraceutical ingredient or conveyor for the intake of medicinal plants? Evidence from Paraguayan folk medicine." Evidence-Based Complementary and Alternative Medicine Volume 20I8, I7 pages; https://doi.org/ıo.II55/2018/6849317

Kujawska, Monik,a and Łukasz Łuczaj. 2015. "Wild edible plants used by the Polish community in Misiones. Argentina." Human Ecology 43 (6), 855-869.

Kujawska, Monika, and Andrea Pieroni. 20I5. "Plants used as food and medicine by Polish migrants in Misiones, Argentina." Ecology of Food and Nutrition 54, 255-279.

Kuzemko, Anna A., and Thomas Becker, Yakiv P. Didukh, Ioana V. Ardelean, Ute Becker, Monica Beldean, Christian Dolnik, Michael Jeschke, Alireza Naqinezhad, Emin Uğurlu, Aslan Ünal, Kiril Vassilev, Evgeniy I. Vorona, Olena H. Yavorska, Jurgen Dengler. 20I4. "Dry grassland vegetation of Central Podilia (Ukraine) - a preliminary overview of its syntaxonomy, ecology and biodiversity." Tuexenia 34, 391-430.

Lanska, Dagmar, and Pavel Zilak. 1992. Jadalne rośliny dziko rosnące. Warsaw: Delta W-Z.

Leach, Helen. 2003. "Human Domestication Reconsidered." Current Anthropology 44 (3), 349-368.

Lins Neto Ernani M.F, and Nivaldo Peroni, Alejandro Casas, Fabiola Parra, Xitlali Aguirre, Susana Guillén, Ulysses P. Albuquerque. 20I4. "Brazilian and Mexican experiences in the study of incipient domestication." Journal of Ethnobiology and Ethnomedicine Io (33), [without pagination] https://doi.org/IO.II86/1746-4269-IO-33.

Litvinskaja, Svetlana A., and Ramzan A. Matuzaliev. 2013. Flora Severnogo Kavkaza, Atlas-Opredelitel'. Moscow: Izd. "Fiton XXI".

Łuczaj, Łukasz. 2010. "Changes in the utilization of wild green vegetables in Poland since the rith century: a comparison of four ethnobotanical surveys." Journal of Ethnopharmacology 128, 395-404.

Mahato, Shashi. 2000. "Bioactive saponins from some plants used in Indian traditional medicine." In Saponins in Food, Feedstuffs and Medicinal Plants, edited by Wiesław Oleszek and Andrew Marston, 13-23, Dordrecht: Kluwer Academic Publishers.

Marder, Michael. 2013. Plant Thinking. A Philosophy of Vegetal Life. New York: Columbia University Press.

Martin, Gary J. 2004. Ethnobotany: a Methods Manual. London, Sterling (Vancuver): Earthscan.

Martínez-Crovetto, Raúl. 1968. "La alimentación entre los indios Guaranies de Misiones (República Argentina)." Etnobiologica 4, I-24.

Matuzaliev, Ramzan. 20I6. "Analiz Raspredelenija Vidov Flory Dagestana." Botanicheskiy Zhurnal IoI (9), 1056-1074.

McKey, Doyle, and Timothy R. Cavagnaro, Julie Cliff, Roslyn Gleadow. 20Io. "Chemical ecology in coupled human and natural systems: people, manioc, multitrophic interactions and global change." Chemoecology 20, I09-133.

Merritt, C.R. 1986. "The relationship between the rate of entry of ioxynil and effects on photosynthesis in normal and drought stressed Stellaria media." Annals of Applied Biology I08, I05-II4.

Moerman, Daniel E. 1994. "North American food and drug plants." In Eating on the Wild Side. The Pharmacologic, Ecologic and Social Implications of Using Noncultigens, edited by Nina L. Etkin, 166-I8I, Tucson: The University of Arizona Press.

Montenegro, Pedro de. I71o. Materia Medica Misionera. Buenos Aires: Biblioteca Nacional. 
Noorani, Tehseen, and Julian Brigstocke. 20I8. "More-Than-Human participatory research." In Connected Communities Foundation Series, edited by Keri Facer and Katherine Dunleavy, Bristol: University of Bristol/AHRC Connected Communities Programme.

Osbourn, Anne, and Jonathan Carter, Kalliope Papadopoulou, Kosmas Haralampidis, Miranda Trojanowska, Rachel Melton. 2000. "Oat root saponins and root-infecting fungi." In Saponins in Food, Feedstuffs and Medicinal Plants, edited by Wiesław Oleszek and Andrew Marston, I2I-I28, Dordrecht: Kluwer Academic Publishers.

Pálsson, Gísli. 1996. "Human-environment relations: orientalism, paternalism and communalism." In Nature and Society. Anthropological Perspectives, edited by Philippe Descola and Gísli Pálsson, 63-8I, London and New York: Routledge.

PFAF https://pfaf.org/user/plant.aspx?LatinName=Stellaria+media (accessed 21.03.2020).

Pin, Ana, and Gloria Céspedes, eds. 2009. Plantas medicinales del Jardín Botánico de Asunción. Asunción: Dirección General de Gestión Ambiental Municipalidad de Asunción.

Pirożnikow, Ewa. 20I4. "Rola pożywienia zbieranego z natury w życiu Polaków deportowanych do ZSRR w okresie drugiej wojny światowej." Etnobiologia Polska 4, I35-I72.

Popov, Aleksej P. 1969. Lekarstvennye rastenija v narodnoj medicine. Kiev: "Zdorovja".

Rao, Venket A., and Debbie M. Gurfinkel. 20oo. "Dietary saponins and human health." In Saponins in Food, Feedstuffs and Medicinal Plants, edited by Wiesław Oleszek and Andrew Marston, 255-270, Dordrecht: Kluwer Academic Publishers.

Reinert, Hugo. 2019. "The midwife and the poet: bioaccumulation and retroactive shock." Environmental Humanities II (I) [without pagination] https://doi.org/IO.I215/220II919-7349455.

Schmeda Hirschmann, Guillermo. 1998. "Ethnobotanical observations on Paraguayan Myrtaceae." I. Journal of Ethnopharmacology 22; 73-79.

Silva, D.H.S., and C.V. Plaza, V. da S. Bolzani, J.A. Cavalheiro, J. Castro-Gamboa. 2006. "Antioxidants from fruits and leaves of Eugenia jambolana, an edible Myrtaceae species from Atlantic Forest." Planta Medica 72: 187, https://doi.org/I0.I055/s-2006-949987.

Somme, Laurent, and Laura Moquet, Muriel Quinet, Maryse Vanderplanck, Denis Michez, Georges Lognay, Anne-Laure Jacquemart. 2016. "Food in a row: urban trees offer valuable floral resources to pollinating insects." Urban Ecosystems 19, II49-II6I.

Stankov, Stanko, and Hafize Fidan, Tanya Ivanova, Albena Stoyanova, Stanka Damyanova, Mykola Desyk. 20I8. "Chemical composition and application of flowers of false acacia (Robinia pseudoacacia L.).” Ukrainian Food Journal 7, 577-588.

Sytnyk, Svitlana, and Viktoriia Lovynska Yuriy, Gritsan. 20I6. "The analysis of the taxation structure Robinia pseudoacacia L. Stands in The Forests Whithin of Northern Steppe, Ukraine." Agriculture \& Forestry 62(4), I53-160.

Tava, Aldo, and Marcella Chiari, Wiesław Oleszek. 200o. "Separation of alfalfa (Medicago sativa L.) saponins as their borate complexes by capillary electrophoresis." In Saponins in Food, Feedstuffs and Medicinal Plants, edited by Wiesław Oleszek and Andrew Marston, 43-56, Dordrecht: Kluwer Academic Publishers.

The Plant List. http://www.theplantlist.org/ (accessed I0.09.2020).

Thomas, Evert, and Ina Vandebroek, Patrick Van Damme. 2007. "What works in the field? A comparison of different interviewing methods in ethnobotany with special reference to the use of photographs." Economic Botany 6I(4), 376-384.

Tsing Lowenhaupt, Anna. 2015. The Mushroom at the End of the World. On The Possibility of Life in Capitalist Ruins. Princeton and Oxford: Princeton University Press.

Turkington, Roy, and Norman C. Kenkel, Gail D. Franko. 1980. "The biology of Canadian weeds. 42. Stellaria media (L.)Vill." Canadian Journal of Plant Science 60, 981-992. 
Týskiewicz, Katarzyna, and Marcin Konkol, Rafał Kowalski, Edward Rój, Kazimierz Warmiński, Michał Krzyżaniak, Łukasz Gil, Mariusz Stolarski. 2019. "Characterization of bioactive compounds in the biomass of black locust, poplar and willow." Trees 33, I235-I263.

Van der Veen, Marijke. 20I4. "The materiality of plants: plant-people entanglements." World Archeology $46(5), 799-812$.

Whittaker, R.H., and P.O. Feeny. 1971. "Allelochemicals: Chemical interactions between species." Science I7I, 757-770.

Willis, Paul. 2000. The Ethnographic Imagination. Cambridge: Polity.

Witzany, Günther. 2006. "Plant communication from biosemantic perspective: Difference in abiotic and biotic signal perception determine content arrangement of response behaviour." Plant Signalling and Behaviour I(4), I69-178.

Table I. Species of the Myrtaceae botanical family used by non-native population of Misiones Argentina

\begin{tabular}{|c|c|c|c|c|}
\hline Botanical name & Local name & $\begin{array}{l}\text { Plant part } \\
\text { used }\end{array}$ & $\begin{array}{l}\text { Category } \\
\text { of use }\end{array}$ & Use \\
\hline $\begin{array}{l}\text { Calycorectes riedelianus } \\
\text { O. Berg [syn. Eugenia } \\
\text { psidifloraO.Berg] }\end{array}$ & guaporai'ti (Eur.)* & fruit & food & raw snack \\
\hline \multirow{2}{*}{$\begin{array}{l}\text { Campomanesia } \\
\text { guaviroba (DC.) Kiaersk. } \\
\text { en Warming }\end{array}$} & \multirow[t]{2}{*}{ ñandu>apysa $(\text { Par. })^{*}$} & fruit & food & raw snack \\
\hline & & bark & medicine & diarrhoea \\
\hline \multirow{3}{*}{$\begin{array}{l}\text { Campomanesia } \\
\text { guazumifolia (Cambess.) } \\
\text { O.Berg }\end{array}$} & \multirow{3}{*}{$\begin{array}{l}\text { sietecapotes (Eur., Par.), } \\
\text { ñandu>apysa (Par.), } \\
\text { grüner Apfel (Ger.) }\end{array}$} & fruit & food & raw snack \\
\hline & & leaves & \multirow[t]{2}{*}{ medicine } & diarhoea, empacho \\
\hline & & bark & & dermatological - skin burn \\
\hline \multirow{2}{*}{$\begin{array}{l}\text { Campomanesia } \\
\text { xanthocarpaO.Berg, } \\
\text { en Mart. }\end{array}$} & \multirow[t]{2}{*}{$\begin{array}{l}\text { guavirá (Eur., Par.), } \\
\text { ñandu apysa (Par.) }\end{array}$} & fruit & food & $\begin{array}{l}\text { raw snack, sweet } \\
\text { preserves }\end{array}$ \\
\hline & & leaves & medicine & $\begin{array}{l}\text { diarrhoea, hypertension, } \\
\text { uric acid, appendix, } \\
\text { pharyngitis, coughs, } \\
\text { diabetes, feet bad smell }\end{array}$ \\
\hline Eucaliptuscfr. saligna Sm. & eucalipto (Eur.; Par.) & leaves & medicine & $\begin{array}{l}\text { coughs, bronchitis, } \\
\text { respiratory problems, } \\
\text { hot remedy }\end{array}$ \\
\hline Eugenia involucrata DC. & $\begin{array}{l}\text { cerella (Eur., Par.); } \\
\text { dzika czereśnia (PI.) }\end{array}$ & fruits & food & raw snack; fruit wine \\
\hline Eugenia myrcianthesNied. & ubajay (Eur.) & fruits & food & sweet preserves, juice \\
\hline \multirow[t]{2}{*}{$\begin{array}{l}\text { Eugenia pyriformis } \\
\text { Cambess. }\end{array}$} & \multirow[t]{2}{*}{$\begin{array}{l}\text { yva hai (Eur., Par.); } \\
\text { sourer Apfel(Ger.) }\end{array}$} & fruits & food & $\begin{array}{l}\text { raw snack; fruit wine; } \\
\text { sweet preserves }\end{array}$ \\
\hline & & $\begin{array}{l}\text { leaves, } \\
\text { bark }\end{array}$ & medicine & $\begin{array}{l}\text { hypertension, high levels } \\
\text { of cholesterol, diabetes, } \\
\text { uric acid, anxiety, } \\
\text { digestion problems, } \\
\text { diarrhoea }\end{array}$ \\
\hline
\end{tabular}




\begin{tabular}{|c|c|c|c|c|}
\hline Botanical name & Local name & $\begin{array}{l}\text { Plant part } \\
\text { used }\end{array}$ & $\begin{array}{l}\text { Category } \\
\text { of use }\end{array}$ & Use \\
\hline \multirow[t]{2}{*}{ Eugenia uniflora L. } & \multirow{2}{*}{$\begin{array}{l}\text { pitanga (Eur., Par.), } \\
\text { ñangapiry (Par.) }\end{array}$} & fruit & food & raw snack, fruitwine \\
\hline & & leaves & medicine & $\begin{array}{l}\text { hypertension, high } \\
\text { levels of cholesterol, uric } \\
\text { acid, diabetes, vomits, } \\
\text { diarrhoea, pharyngitis, } \\
\text { cold remedy, anxiety }\end{array}$ \\
\hline $\begin{array}{l}\text { Myrcianthespungens } \\
\text { (O. Berg) D. Legrand }\end{array}$ & guaviju (Par.) & fruit & food & raw snack \\
\hline \multirow{2}{*}{$\begin{array}{l}\text { Plinia rivularis (Cambess.) } \\
\text { Rotman }\end{array}$} & \multirow[t]{2}{*}{ guaporaity (Eur., Par.) } & fruit & food & raw snack \\
\hline & & bark & medicine & diarrhoea \\
\hline \multirow{3}{*}{$\begin{array}{l}\text { Plinia trunciflora (O. Berg) } \\
\text { Kausel [syn. Plinia } \\
\text { peruviana (Poir.) Govaerts }\end{array}$} & \multirow{3}{*}{$\begin{array}{l}\text { yaboticaba (Eur., Par.); } \\
\text { yva puru (Par.) }\end{array}$} & fruit & food & raw snack, fruit wine \\
\hline & & fruit skin & \multirow[t]{2}{*}{ medicine } & diarrhoea \\
\hline & & leaves & & hypertension \\
\hline $\begin{array}{l}\text { Psidiumcfr. } \\
\text { australeCambess. }\end{array}$ & guayava (Eur.) & fruit & food & raw snack \\
\hline \multirow[t]{2}{*}{ Psidium guajava L. } & \multirow[t]{2}{*}{$\begin{array}{l}\text { guayava (Eur., Par.), } \\
\text { arasa (Par.) }\end{array}$} & fruit & food & $\begin{array}{l}\text { raw snack, dessert, } \\
\text { sweet preserves }\end{array}$ \\
\hline & & leaves & medicine & $\begin{array}{l}\text { diarrhoea, toothache, } \\
\text { pharyngitis, coughs, } \\
\text { common cold }\end{array}$ \\
\hline \multirow[t]{2}{*}{ Psidium guineense Sw. } & \multirow[t]{2}{*}{$\begin{array}{l}\text { guayava (Eur., Par.), } \\
\text { arasa (Par.) }\end{array}$} & fruit & food & $\begin{array}{l}\text { raw snack, dessert, } \\
\text { sweet preserves }\end{array}$ \\
\hline & & leaves & medicine & diarhoea, toothache \\
\hline
\end{tabular}

Legend: *(Par) - names used by Paraguayan migrants; (Eur) - names used by European migrants and their descendants; (Ger.) - names used by German migrants and their descendants; (Pl.) - names used by Polish migrants.

\section{AUTHORS' CONTACT:}

Iwa Kołodziejska

Institute of Slavic Studies, Polish Academy of Sciences

e-mail: iwa.kolodziejska@ispan.waw.pl

ORCID: 0000-0003-1590-1760

Monika Kujawska

Institute of Ethnology and Cultural Anthropology, University of Lodz e-mail: monika.kujawska@uni.lodz.pl

ORCID: 0000-0002-5643-34I7

$$
\text { (C) }(1) \Theta
$$

